\title{
Resepsi Teks Pararaton: dari Serat ke Novel
}

\author{
Abdul Hakim \\ SD 3 Negeri Danger, Lombok Timur, NTB \\ abdulhakimtimbak@yahoo.com
}

\begin{abstract}
Abstrak
Tulisan ini dilatarbelakangi oleh hadirnya novel Pararaton sebagai bentuk baru teks Pararaton. Permasalahannya adalah bagaimana teks Pararaton diresepsi ke dalam bentuk novel. Tulisan ini bertujuan untuk menjelaskan perbedaan novel dengan teks klasik Pararaton dan menunjukkan adanya inversi dalam bentuk novel yang disesuikan dengan horizon harapan pembaca masa kini. Untuk menjawab permasalahan tersebut ini, tulisan ini menggunakan teori resepsi Hans Robert Jauss dan metode fenomenologi. Tulisan ini menunjukkan beberapa hasil analisis. Pertama, novel Pararaton menujukkan sebuah penceritaan yang kaya dengan pendetailan narasi dibandingkan Pararton versi naskah klasik. Kedua, Novel Pararaton juga menunjukkan kreasi pada penggambaran tokoh Ken Arok, Ken Dedes, dan Tunggul Ametung. Kreasi itu berhubungan dengan horizon harapan masyarakat masa kini. Ketiga, novel Pararaton sebagai klise teks klasik Pararaton, klise tokoh atau penokohan, setting cerita, dan alur. Keempat, novel Pararaton dihadirkan dengan narasi penuh etik penggambaran Tunggul Ametung dan Ken Arok.
\end{abstract}

Kunci: novel Pararaton, resepsi, horizon harapan, invensi

\begin{abstract}
This paper is ground by the presence of novel Pararaton as a new form of text Pararaton. The problem in this paper is how the Pararaton text is perceived into a novel form. This paper aims to explain the novel differences with the classic Pararaton texts and to show an inversion in the form of a novel that is adapted according to the horizon of today's readers' expectations. To address this problem, this paper uses Hans Robert Jauss' reception theory and phenomenology methods. This paper shows some analysis results. First, the novel Pararaton shows richer with narrative detailing than the Pararaton text. Secondly, Novel Pararaton also shows the creation of the depiction of Ken Arok, Ken Dedes, and Tunggul Ametung. The creations relate to the expectations horizon of today's society. Third, Pararaton's novel as a reflection of Pararatonic classical texts, figures or characterizations, story settings, and grooves. Fourth, the novel Pararaton presented with a full ethical narrative in describing the characters Tunggul Ametung and Ken Arok.
\end{abstract}

Key word: novel Pararaton, reception, the expectation horizon, inversion

\section{A. Introduction}

Resepsi teks klasik ke dalam bentuk baru, misalnya novel, mulai mengemuka dewasa ini. Banyak ditemukan novel yang meresepsi teks masa lampau ke dalam bentuk 
karya masa kini yang seolah-olah menggambarkan kesamaaan seperti pada novel Pararaton, Centini, Mahabarata, Gajah Mada, dan lain-lain. Sebagai sebuah karya sastra lama atau karya masa lampau, ia hadir dengan sistemnya sendiri, begitu pula dengan yang hadir dan dihadirkan ke masa kini. Hadirnya ke masa kini tentu tidak tanpa suatu kecenderungan estetik tertentu. Sebagai suatu entitas yang tidak mandiri maka perlu untuk ditinjau lebih jauh dan mendalam hubungan diantara keduanya, sebab variabel masa lampau tidak bisa diabaikan begitu saja karena ia mengkonstruksi masa kini. Hal itulah yang akan dilihat dalam karya yang muncul belakangan seperti novel Pararaton, bagaimana ia dihadirkan pada masa kini? Dan mengapa dihadirkan kembali? Serta, bagaimana hubungan diantara kedua karya dengan penghadiran dalam bentuk yang berbeda? Pentingnya melihat novel Pararaton karena novel itu berisi kisah para raja di Jawa. Teks Pararaton sudah diteliti Dewi (2013). Dewi melihat trasformasi teks Pararaton ke dalam novel Arok Dedes karya Pramoedya Ananta Toer. Menurut Dewi, mitos Dedes berhasil diangkat oleh Pramodya ke dalam sastra Indonesia modern. dalam sastra Indonesia modern, Dedes berperan penting dalam percaturan politik, kekuasaan dan negara. Di dalam teks klasik, peran Dedes tidaklah menonjol, sedangkan dalam novel Arok Dedes, peran Dedes menjadi sentral (Dewi, 2013). Artikel Dewi itu, tidak menjelaskan secara spesifik, aspek apa saja yang bertransformasi. Memang, Dewi fokus pada tokoh Dedes. Fokus demikian tidak dibingaki dengan teori yangv relevan. Padahal, transformasi teks Pararaton ke dalam novel Arok Dedes karya Pramoedya merupakan bentuk resepsi Pramoedya terhadap serat Pararaton. Resepsi itu ditunjukkan pada aspek tokoh yang disesuaikan dengan semanagat zaman atau horizon harapan pembaca masa kini. Oleh karena itu, penting melihat kembali resepsi teks Pararaton ke dalam bentuk novel.

Persoalan di atas membawa kepada konsep teoritis yakni resepsi Hans Robert Jauss tentang resepsi pembaca yang didasarkan atas horizon harapan. Horizon harapan ini memediasi antara penerimaan pribadi dan publik dari karya sastra. Jauss (1982) mengatakan bahwa karya sastra baru atau masa kini membangkitkan lagi karya lama yang hampir terlupakan. Artinya, karya sastra lama diterima ke dalam masa kini yakni melalui sebuah resepsi dengan memasukkan horizon harapannya. Bentuk resepsi ini adalah bagian dari ia mengembalikan atau menariknya sesuai dengan semangat zaman masyarakatnya. Hal demikian disebabkan karena masyaakat pada umumnya dan 
sebagian besar tidak tertarik dengan bentuk lama, sehingga perlu dikemas ke dalam bentuk yang lebih baru kalaupun isinya sama dan mungkin hampir sama.

Menurut Jauss (1982), karya sastra baru bukan hanya berkategori estetis dalam bentuk inovasi, kejutan, pengunggulan, penyusunan ulang, alienasi, tetapi juga merupakan kategori historis, yaitu untuk mempersoalkan momen historis apa yang dibuat oleh pengarang. Sehingga, yang terpenting dalam melihat karya masa kininya adalah pada momen historis yang pengarang tuliskan, apakah ia kemudian memperkuat, menolak dan mungkin melampaui yang historis tadi dengan memasukkan harapannya dengan melihat kondisi masyarakatnya. Jauss (1982) mengatakan bahwa kemunculan karya sastra dapat dilihat pada apakah ia memenuhi, melampaui, mengecewakan atau menyangkal harapan pembaca pertamanya. Sebagai karya yang hadir dalam konteks masa kini maka aspek itu penting untuk ditinjau pada posisi mana ia berada. Namun, yang paling penting bahwa sebuah karya sastra ketika muncul dipandang sebagai karya baru, walaupun sesungguhnya tidak menunjukkan sebagai karya yang benar-benar baru, melainkan akan dinilai sejauh mana karya sastra itu mampu mempengaruhi pembacanya (Jauss, 1982).

Teori estetika resepsi Jauss (1982) berkaitan dengan pemahaman makna karya sastra dan pemahaman bentuk karya sastra. Pemahaman akan bentuk ini sebagai akibat adanya perubahan historis tradisi masyakarat dalam melihat suatu bentuk dan akibat pengaruh dari sistem modern yang datang dari Barat. Dalam perspektif historis hal demikian selalu berbenturan dan bersinggungan baik dari aspek bentuk maupun isinya. Keindahan sastra adalah keselarasan antara bentuk dan isi. Bentuk (sastra) yang baru muncul tidak hanya untuk mengkritik bentuk lama, tetapi juga memunculkan persepsi baru tentang isi yang dikandungnya. Perihal melihat secara historis ini membawa pada perspektif diakronik suatu karya. Perspektif diakronik adalah suatu pemahaman sejarah atas homogenitas karya sastra dilihat dari kronologi kejadian dan lingkungan kehidupannya (Jauss, 1982). Dalam perspektif diakronik ini dapat dijelaskan perubahanperubahan atau inovasi-inovasi.

Resepsi sastra dimaksudkan bagaimana pembaca memberikan makna karya sastra yang dibacanya, sehingga dapat memberikan reksi tanggapan terhadapnya (Junus, 1985: 1). Terdapat dua tanggapan atas sebuah karya yakni yang sifatnya aktif dan pasif. Perbedaan keduanya terletak pada bagaimana ia merealisasikannya. Yang pasif hanya 
sampai pada pemahaman akan hakikat karya tersebut, sedangkan yang aktif sampai pada menghasilkan sesuatu yang baru dengan merealisasikannya ke bentuk karya lagi, seperti pada perubahan bentuk karya dari bentuk lama ke bentuk modern. Inilah yang akan ditinjau dalam tulisan ini yakni meninjau novel Pararaton sebagai sebuah bentuk baru yang bersumber dari bentuk lama yakni Serat Pararaton dengan melihat kontinuitasnya.

\section{B. Metode Penelitian}

Berdasarkan pada teori yang digunakan, tulisan ini menggunakan metode fenomenologi. Metode fenomenologi mengasumsikan bahwa teks adalah fenomena. Sebagai fenomena, teks adalah hasil pengalaman pengarang membaca teks lain yang mempunyai bentuk yang berbeda, yaitu teks klasik. Munculnya teks baru, novel, berdasarkan pada teks lama. Artinya, kesadaran pengarang mengenai cerita Pararaton adalah hasil pengalaman membaca teks klasik. Kesadara pengarang mengenai cerita Pararaton tidak pernah keluar dari formula teks yang ada. Yang membedakan teks klasik dengan teks masa kini adalah semanagat zaman atau horizon harapan pembaca. Dalam konteks inilah, makna teks ditentukan oleh pembaca masa kini. Pembacannya terhadap teks dilingkupi oleh sistem norma masa kini. Kesadaran itu mewujud dalam bahasa sehingga bahasa adalah objek material tulisan ini, sedangkan objek formal adalah makna novel dan horizon pengarang sebagai pembaca.

\section{Pembahasan}

\section{Novel Pararaton sebagai Klise Serat Pararaton}

Novel Pararaton secara intrinsik hampir sama dengan Serat Pararaton. Dikatakan demikian karena memang ada perbedaan penggambaran pada beberapa tokoh seperti pada tokoh Ken Arok, Ken Dedes, dan Tunggul Ametung. Dari aspek alur dan setting antara keduanya memiliki persamaan termasuk juga nama tokoh-tokoh dalam bentuk novel dan serat. Penceritaan dari lahirnya Ken Arok sampai ia mati secara garis besar sama, kalaupun ada perbedaan pencitraan yang dilakukan Wid Kusuma sebagai penulis novel. Kusuma tidak melakukan inovasi secara keseluruhan dalam novelnya, namun hanya sedikit melakukan kreasi dan imajinasi dalam penceritaannya. Kreasi yang dilakukan pada cara ia menceritakan kembali isi Pararaton dengan konvensi sastra 
masa kini. Ia menata cerita dengan baik dalam penyajian kembali Serat Pararaton. Ia sedikit mengkreasikan tokoh-tokoh utama menjadi tokoh sebagaimana mestinya tokoh dalam pengertian panutan atau figure.

Selanjutnya, Kusuma melakukan sedikit imajinasi tambahan sebagaimana layaknya novel yang dalam perspektif tertentu kekuatan imajinasi menjadi signifikan di dalam dalamnya. Kekuatan imajinasi ini ditunjukkan pada adegan perang antara kerajaan Daha dengan Tumapel. Kusuma dengan detail bercerita bagaimana perang dilakukan, termasuk kedetailan bagaimana Ken Arok mampu mengalahkan Tunggul Ametung ketika pertarungan keduanya menjadi salah satu syarat untuk dia didukung menjadi raja, termasuk adegan perang Ken Arok mengalahkan raja Daha beserta kematian para patihnya.

Apa yang dilakukan oleh Kusuma dalam novel itu adalah menghadirkan cerita dengan semangat zaman dan konvensi bentuk yang dipilih. Itulah yang membedakan antara bentuk novel dengan bentu serat. Bentuk novel lebih kaya dari aspek penceritaannya, sedangkan pada serat lebih mengedepankan isi tanpa banyak melakukan penceritaan secara kuantitatif. Bentuk Serat lebih padat dibandingkan dengan bentuk novel. Kepadatan dalam ia menyampaikan pesan atau nilai dibandingkan novel yang banyak bermain imajinasi dan bahkan fantasi dari pengarangnya. Hadirnya variabel imajinasi dalam novel Pararaton berdampak pada kuantitas karya yang menjadi panjang dalam pencertitaannya, tetapi bukan berarti bentuk serat tidak ditemukan apa yang disebut imajinasi hanya saja tidak banyak dieksplorasi detail seperti dalam novel.

Novel sebagai sebuah klise dan atau cermin dari bentuk serat berkemungkinan sama atau hampir sama dan bahkan berbanding terbalik dalam kasus-kasus novel-novel tertentu. Kalau dalam konteks Ken Dedes seperti dalam novel Ken Dedes Sang Penggoda karya Wawan Susetya, ia digambarkan menjadi perempuan yang agresif yang menggoda Ken Arok. Dalam konteks Pararaton, novel tersebut hanyalah sebuah klise sekaligus cermin, sehingga novel Pararaton mengklise Serat Pararaton dan sebagai cermin Serat Pararaton. Sebagai cermin, ia memiliki kesamaan, namun tidak menutup kemungkinan cerminnya sedikit pecah sehingga tidak persis sama, artinya bekemungkinan terlihat kecacatan oleh karena cerminnya yang retak.

Sebagai klise, dapat dilihat, pertama, pada judul cerita dari Serat Pararaton menjadi novel Pararaton yang tentunya melekat karakateristik novel dalam 
penceritaannya misalnya dalam hal kekuatan imajinasi. Kedua, klise nama tokoh. Nama-nama tokoh dalam novel Pararaton sama dengan nama tokoh dalam Serat Pararaton mulai dari nama orang tua Ken Arok, nama-nama orang yang pernah menjadikannya anak, nama-nama orang yang menolongnya, nama-nama orang yang menjadi gurunya, nama-nama tempat yang ia kunjungi, nama-nama pristiwa yang dialaminya, juga nama-nama gelar yang melekat padanya dan tokoh-tokoh yang lain. Ketiga, klise pada alur cerita. Penceritaan pristiwa mulai dari lahirnya Ken Arok, dibesarkannya Ken Arok oleh seorang pencuri, juga diangkatnya Ken Arok oleh seorang penjudi, pristiwa-pristiwa ketika ia mencuri dan merampok, pristiwa ketika ia diselamatkan langsung oleh Dewa, peristiwa bertemunya dengan Brahmana Lohgawe sampai ia menjadi prajurit di Tumapel, peristiwa pembunuhan Tunggul Ametung, sampai pristiwa Ken Arok menjadi Raja dan mati oleh keris Empu Gandring.

Keempat, klise penokohan. Hal-hal yang berkaitan dengan tokoh dalam novel pararaton dengan serat memiliki persamaan. Dapat dilihat pada bagaiamana tokoh Ken Arok ditokohkan oleh Wid Kusuma, termasuk mengenai asal, proses, dan tujuan dilahirkan Ken Arok. Kusuma menggambarkan seperti dalam serat bahwa Ken Arok yang lahir dari seorang perempuan bernama Ken Endok. Ken Arok yang lahir dengan misi membawa kemakmuran dan ketentraman di tanah Jawa, Ken Arok yang ditakdirkan menjadi raja, termasuk ketika ia ditakdirkan sebagai pembunuh Tunggul Ametung sebagai jalan ia mendapat Ken Dedes dan menjadi raja di Tumapel, juga takdirnya yang harus mati tertusuk keris Empu Gandring. Begitu pula dengan penggambaran Ken Dedes dan Tunggul Ametung. Kusuma menceritakan Ken Dedes yang berasal dari sebuah desa bernama Panawijen, seorang perempuan cantik anak dari seorang Budis Mahayana bernama Empu Purwa. Mengenai tokoh Tunggul Ametung, Kusuma tidak menceritakan darimana ia berasal, tidak menceritakan seperti ia menceritakan Ken Arok yang merupakan keturunan Dewa Brahma. Nampaknya, ia tidak berani berspekulasi lebih jauh dalam menggambarkan tokoh Tunggul Ametung. Namun, Kusuma hanya sampai pada penggambaran sikap dan cara ia bersikap sebagai seorang raja di Tumapel.

Dalam novel tersebut, ditemukan klise pada karakterisasi tokoh Ken Arok. Terdapat perubahan karakter seperti yang terdapat di dalam serat Pararaton. Kusuma mengklisekan karakter Ken Arok dari yang tidak baik menjadi sangat baik. Hal itu 
terlihat pada fase awal kemunculan dan fase akhir dari perjalanannya mencapai misi. Di awal cerita Ken Arok dicitrakan tidak baik sebagai seorang pencuri, perampok, dan pemerkosa. Namun, di fase-fase akhir Ken Arok menjadi sosok yang berprilaku baik, menjadi prajurit yang baik yang membuatnya naik pangkat menjadi pengawal pribadi raja, menjadi raja yang mampu membawa ketentraman bagi kerajaan Tumapel, menjadi anak angkat yang tahu balas budi kepada orang-orang yang telah mengangkatnya menjadi anak dan orang-orang yang pernah menolongnya. Hal itu dilakukannya ketika ia sudah berhasil mendapat posisi di kerajaan. Ketika Ken Arok balik lagi ke desa-desa yang pernah dulu ia tinggali, terutama kepada orang tua angkatnya, ia memberikan pertolongan materi kepada mereka sebelum ia meninggalkannya lagi.

\section{Ken Arok, Ken Dedes, dan Tunggul Ametung dalam Novel Pararaton}

Novel Pararaton adalah novel yang dibuat berdasarkan Serat Pararaton. Novel yang merupakan hasil resepsi Wid Kusuma atas Serat Pararaton. Novel dan serat adalah dua bentuk karya yang secara diakoronis dan tradisi bersastra keduanya berbeda. Secara diakronis, serat adalah bentuk karya yang sifatnya tradisional dalam kesusastraan klasik, sedangkan novel adalah bentuk karya yang muncul kemudian setelah tradisi Barat masuk ke Nusantara. Inilah yang disebut Jauss (1982) dengan pemaknaan bentuk karya sastra. Bentuk lama diresepsi ke bentuk yang baru, resepsi sebuah serat ke dalam bentuk novel.

Menurut Jauss (1982), karya sastra tersebut sebagai sebuah objek, dengan demikian bukanlah sebuah objek yang statis dan menawarkan pandangan yang sama dalam setiap periode. Adanya bentuk yang berbeda antara serat dan novel adalah salah satu wujud adanya pandangan yang berbeda yang dimiliki masyarakat dalam melihat karya sastra. Pandangan yang terepresentasi pada bagaimana ia melukiskan kembali cerita atau tokoh dalam bentuk yang sama sekaligus berbeda. Hal itu dapat dilihat pada novel Pararaton yang ditulis kembali oleh Wid Kusuma. Kusuma meresepsi bentuk Serat Pararaton ke dalam bentuk novel Pararaton. Salah satu bentuk resepsinya ia melukiskan Tunggul Ametung sebagai sosok yang beretika baik ketika ia ingin memperistri Ken Dedes. Tunggul Ametung dengan sikap yang baik memboyong Ken Dedes ke Istana Tumapel. Di dalam bentuk serat, Ken Dedes diambil paksa serta langsung disetubuhinya begitu sampai di keraton tanpa dengan jelas menceritakan 
proses yang harus dilalui sebelum ia berhak melakukan itu. Sebelum diperistrinya Ken Dedes oleh Tunggul Ametung, Kusuma mencitrakan berbeda atas peristiwa itu menjadi lebih etis, bahwa Tunggul Ametung dengan sopan meminta dan menunggu acara pernikahan selesai untuk menyetubuhinya. Inilah yang disebut Jauss dengan pemaknaan yang sesuai dengan semangat zamannya. Reproduksi kembali sebuah karya lama adalah untuk menyajikan pembaca sebuah karya yang lebih mudah dipahami dari pada versi aslinya dan memasukkan horizon harapannya seperti ketika Kusuma secara eksplisit merubah etika Tunggul Ametung pada adegan ia mengunjungi dan tertarik pada Ken Dedes. Perubahan penggambaran sikap tersebut adalah upaya penulis untuk membangun citra yang baik pada tokoh legendaris di pula Jawa yakni Raja Tumapel. Implikasinya bahwa generasi yang membacanya tidak berpandangan negatif terhadap tokoh tersebut yang dalam tahap-tahap tertentu menjadi figure yang mesti dicontoh. Penggambaran tersebut adalah upaya penulis membangun estetika yang berbeda pada satu aspek yang dianggapnya sesuai dengan semangat zamannya.

Karya lama yang diasumsikan memiliki nilai yang tinggi yang di dalamnya menceritakan bagaimana pendahulunya hidup dan cara ia hidup dan menyikapi kehidupan. Adanya asumsi itu membuat karya lama dihadirkan kembali ke dalam bentuk yang baru sebagai upaya menghidupkan kembali karya lama yang hampir terlupakan. Pengembaliannya ke dalam bentuk yang lebih baru dengan harapan untuk bisa lebih diterima oleh pembaca masa kini. Pengembalian tersebut tidak terlepas dari semangat zamannya yakni semangat ketika dunia sastra dan dunia sosial membutuhkan yang lama untuk dia melihat siapa dirinya. Itulah alasan dihadirkannya kembali Pararaton dalam bentuk novel yang kemudian disesuaikan dengan semangat zaman masyarakatnya. Sebagai akibatnya, perkembangan terakhir kesusastraan dewasa ini terdapat banyak sekali novel-novel yang bersumber dari sejarah dan tokoh-tokoh legendaris yang diresepsi ke dalam bentuk yang lebih bisa diterima oleh masyarakat seperti dalam bentuk film atau multimedia.

Novel tersebut secara detail dalam konteks perbedaan aspek temporal berbeda dalam penggambaran tokoh dan peristiwa yang ada di dalam kedua bentuk yang berbeda secara temporal pula. Hal ini dapat dilihat pada penggambaran detail dalam pencitraan tokoh Ken Arok, Tunggul Ametung, dan Ken Dedes. Pencitraan tersebut dapat dilihat pada kutipan berikut ini. 
Hai orang-orang Kabalon, para ajar, para petapa, janganlah orang itu kalian bunuh. Anak ini adalah putraku yang belum selesai menjalankan tugasnya di muka bumi ini. Lepaskan dia (Kusuma, 2012:50).

Kutipan di atas berbeda dengan dalam perspektif wacana dengan pararaton dalam bentuk serat. Kalaupun sekilas pandang bisa dikatakan sama. Dalam serat pararaton tidak dikatakan "Hai orang-orang Kabalon", tetapi langsung mengatakan "Wahai para petapa", juga pada kalimat "belum selesai menjalankan tugasnya di muka bumi" yang di dalam bentuk serat mengatakan "pekerjaannya di dunia masih banyak lagi". Penggunaan kata yang berbeda memiliki maksud dan makna yang berbeda pula. Kusuma memilih diksi "tugas" dan "muka bumi" dalam pencitraan Ken Arok. Pilihan diksi itu berimplikasi bahwa Ken Arok bertugas di Muka Bumi, sedangkan dalam bentuk seratnya mengatakan secara tidak langsung Ken Arok bekerja di dunia yakni membawa kedamaian dan kemakmuran. Pemakain diksi place yang berdampak pada pembatasan wilayah tindakan dari Ken Arok. "Di muka bumi" adalah sebuah place yang terbatas, sedangkan "di dunia" adalah sebuah place sekaligus space. Sebagai space ia meruang dan mewaktu di manapun dan pada situasi apapun, sehingga ia menjadi lebih cair (fluid) (Upston, 2009). Kusuma dengan pilihan diksi seperti itu melakukan pembatasan pada tindakan Ken Arok sebagai seorang titisan dewa Brahma. Pemakaian kata "tugas" pada Ken Arok yang dilakukan oleh Kusuma secara tidak langsung mengabstrakkan tindakan yang akan dilakukan Ken Arok, sebab tugas Ken Arok adalah membawa kedamaian dan kemakmuran bagi tanah Jawa, sehingga ia ditakdirkan menjadi raja. Namun, ketika memakai kalimat "pekerjaan di dunia masih banyak lagi" adalah kalimat yang mengkongkretkan tindakan-tindakan yang akan dilakukan Ken Arok supaya segera dilepaskan dari amukan masyarakat ketika tertangkap mencuri. Pilihan diksi tersebut berimplikasi pada tingkat abstraksi tindakan yang akan dilakukan Ken Arok. Dalam konteks serat hal demikian menjadi persoalan yang sebagaimana mestinya yang tidak terikat oleh aspek temporal dalam penceritaannya, namun sebagai sebuh resepsi hal demikian menjadi hal yang wajar. Kusuma di satu sisi melakukan upaya mengabstrakkan yang kongkret dan di lain sisi mengkongkretkan yang abstrak. Pemakaian diksi "tugas" adalah bentuk pengabstarkan yang kongkret, sedangkan diksi "di muka bumi" adalah upaya mengkongkretkan yang abstrak. Lebih kongkret ketika ada kalimat di mana dia bertugas dengan jawaban di muka bumi dari pada jawaban di 
dunia, sebab diksi "dunia" masih abstrak, karena akan muncul pertanyaan dunia yang mana, apakah dunia di dalam diri, dunia di luar diri atau dunia diantara keduanya, begitu pula kalau dikontekstualisasikan ke dalam konsep place dan space yang ada di dalam kerajaan Tumapel dan Daha, di dalam tokoh seperti Ken Dedes dan Tunggul Ametung.

Ditemukan juga pencitraan yang berbeda kalau dilihat secara detail pada tokoh Ken Dedes dan Tunggul Ametung. Tunggul Ametung tidak serta merta langsung bersetubuh dengan Ken Dedes seperti dalam Serat Pararaton, namun Kusuma dibuat lebih etis pada bagian itu yakni dengan istilah karonsih dan bermatafor dengan memakai istilah "tongkat kelelakian yang akan ditusuk pada keutamaan Ken Dedes." Hubungan karonsih diantara keduanya dilakukan setelah secara resmi diikat dalam hubungan suami istri. Sementara dalam bentuk serat, Tunggul Ametung menyetubuhi Ken Dedes begitu pulang dari Panawijen. Inilah yang disebut Jauss sebagai penerimaan yang sesuai semangat zaman. Dalam meresepsinya, Kusuma memasukkan norma pada zamannya untuk lebih diterima oleh masyarakat. Kusuma (2012: 94) dengan lebih etis menceritaan bahwa Ken Dedes dilamar dan diperistri seorang akuwu yang berkuasa di tlatah Tumapel. Padahal kebenarannya tidak demikian, ia membawa dengan paksa Ken Dedes tanpa sepengatahuan ayahnya, Empu Purwa.

Kusuma menggambarkan Tunggul Ametung sebagai sosok yang memiliki etika. Tunggul Ametung yang tidak berani melakukan hubungan suami-istri sebelum secara resmi menjadi permainsurinya. Ia memiliki kesabaran untuk menunda hasratnya kepada Ken Dedes sampai pada wakatnya. Artinya, Kusuma menghadirkan sosok Tunggul Ametung yang sabar dan memiliki etika dalam mengambil kebijakan dan keputusan.

Kusuma dalam mencitrakan Ken Dedes agakanya berlebihan karena Ken Dedes menurutnya lebih dahulu menaruh hati pada Ken Arok.

Walaupun Ken Arok sering bertemu dan disuruh oleh permainsuri Tunggul Ametung, tetap belum tumbuh rasa simpati untuk jatuh cinta kepadanya. Namun, sebenarnya secara diam-diam Ken Dedes menaruh hati kepada perwira dalam istana yang bernama ken Arok (Kusuma, 2012: 119).

Pencitraan tersebut sebagai akibat bahwa Ken Dedes tidak menyukai Tunggul Ametung karena ia merasa tidak nyaman berada di dekat Tunggul Ametung kalaupun pada akhirnya menjadi suaminya. Itulah alasan yang mungkin bisa diterima kenapa pada saat Ken Arok membunuh Tunggul Ametung dengan keris Empu Gandring Ken Dedes tidak 
mencegahnya, namun membiarkan hal itu terjadi yang dikemudian hari terungkap ketika Anusapati, anak Tunggul Ametung mempertanyakan siapa bapaknya dan saat itulah Ken Dedes bercerita bahwa Ken Aroklah yang membunuh ayahnya.

Di dalam bentuk novel karya Wid Kusuma ini terjadi semacam pembalikan seperti yang terjadi pada Ken Arok yang sebenarnya lebih dulu menyukainya ketika melihat Ken Dedes sewaktu ia menjadi pengawal pribadi dan melihat barang rahasia milik Ken Dedes bersinar atau mengeluarkan cahaya yang kemudian menjadi sebab untuk dia menginginkan Ken Dedes, sebab siapapun yang memiliki perempuan semacam itu maka ia akan menjadi raja besar. Itulah yang menjadi spirit untuk Ken Arok menjalankan dharmanya dan itulah jalan masuk untuk dia menjadi raja yakni dengan mendapatkan Ken Dedes yang kemudian menjadi sebab yang sifatnya duniawi untuk dia membunuh Tunggul Ametung.

Awal Ken Arok menyukainya adalah ketika ia melihat barang rahasianya bersinar yang diistilahkan dengan perempuan Nareswari yakni perempua utama. Kusuma dalam novelnya seringkali mengulang istilah itu bahkan sebelum Ken Arok melihat barang rahasia Ken Dedes. Ken Arok pun mengetahui hal itu setelah ia bercerita kepada Brahmana Lohgawe bahwa perempuan yang bersinar barang rahasianya disebut demikian, namun dalam novel tersebut disituasikan bahwa penyebutan perempuan itu sudah diketahui banyak orang. Tunggul Ametung mengatakan bahwa perjalanannya ke sebuah padepokan mendapat perempuan nareswari (Kusuma, 2012: 116). Sehingga, berkembanglah cerita bahwa akuwu Tumapel memperistri seorang perempuan Nareswari. Kusuma pada situasi seperti itu memfamiliarkan hal itu sehingga tidak terkesan memiliki urgensi. Berbeda halnya ketika Ken Arok bertanya-tanya perempuan macam apa dengan kelebihan semacam itu, membangkitkan rasa penasaran. Dengan cara bercerita demikian, Kusuma membawa pembaca kepada situasi bahwa Ken Dedes tidak lagi istimewa, karena Tunggul Ametung tertarik kepada Ken Dedes karena kecantikan yang nampak secara fisik, titik keberangkatan Tunggul Ametung mengatakan Ken Dedes cantik adalah berdasarkan fisiknya. Berbeda dengan Ken Arok yang mulai suka setelah melihat betis dan barang rahasianya milik Ken Dedes bersinar. 


\section{Kesimpulan}

Novel pararaton adalah bentuk resepsi dari Serat pararaton. Resespsi yang disesuaikan dengan semangat zaman masyarakatnya yang terepsresntasi pada kreasi dan imajinasi cerita. Kreasi-kreasi pada upaya penggamabaran detail cerita. Imajinasiimajinasi pada bagaimana ia membuat cerita menjadi lebih menarik dan logis, menjadi cerita yang tertata secara kesastraan yang kesemuanya itu disesuaikan dengan sistem norma zaman ketika ia dihadirkan kembali berdasar pada sistem norma zamannya. Namun, Kusuma tidak melakukan inovasi cerita yang ekstrim di dalamnya, dengan kata lain ia masih menjaga orisinalitas cerita kalaupun secara diskurus kewacaan tidak demikian. Kusuma hanya memperkaya teks Pararaton dengan imajinasi-imajinasi dan sedikit berkreasi pada wilayah penggambaran tokoh dan cerita yang ia sesuai dengan semangat zamannya.

Novel Pararaton adalah klise dan atau refleksi dari Serat Pararaton. Pertama, dari aspek judul terdapat persamaan. Kedua, ide atau tema cerita. Ketiga, dapat dilihat pada aspek tokoh mulai dari nama dan hal-hal yang berkaitan dengan tokoh. Keempat, dapat dilihat pada peristiwa-peristiwa yang dibangun, tepatnya dari aspek alur cerita. Kelima, pada karakterisasi tokoh-tokoh baik yang sentral maupun yang tidak sentral.

Wid Kusuma menggambarkan Ken Arok sebagai tokoh yang karaterisasinya memiliki perubahan dari tidak baik menjadi baik yakni pada fase awal dan akhir. Tokoh yang mampu membawa kemakmuran bagi tanah Jawa. Begitu pula pada pencitraan Tunggul Ametung yang dicitarakan sebagai tokoh yang memang pantas menjadi panutan. Ken Dedes ialah perempuan yang dicitrakan sebagai perempuan yang lebih dulu menaruh hati pada Ken Arok.

\section{Referensi}

Dewi, T.K.S. 2013. Arok Dedes dan Pararaton: Transformasi dan Dinamika Sastra dalam Wacana Globalisasi Sastra. Atavisme, 16 (1), p. 119-128

Jauss, H. Robert. 1982. Toward an Aestetic of Reception. Menneapolis: University of Minnesota.

Junus, Umar. 1985. Resepsi Sastra, Sebuah Pengantar. Jakarta Gramedia.

Kusuma, Wid. 2011. Pararaton, sebuah novel. Yogyakarta: DIVA Press. 
Mangkudimeja, RH dan Hardjana HP. 1979. Serat Pararaton Ken Arok 2. Jakarta: Depdikbud, Proyek Penerbitan Buku Sastra Indonesia dan Daerah.

1980. Serat Pararaton Ken Arok 3. Jakarta: Depdikbud, Proyek Penerbitan Buku Sastra Indoensia dan Daerah.

Susetya, Wawan. 2012. Ken Dedes Sang Penggoda. Depok: Imania.

Upston, Sara. 2009. Spatial Politics in the Postcolonial Novel. England: Ashgate 